\title{
The Correlation between Family Socioeconomic Status and the Delayed Treatment of Retinoblastoma Patients at Dr. Soetomo General Hospital Surabaya
}

\author{
Nanning Naimatuningsih ${ }^{1}$, Hendrian Dwikoloso Soebagjo ${ }^{2^{\star}}$, Rosy Setiawati ${ }^{3}$, Rozalina Loebis $^{2}$
}

\author{
${ }^{1}$ Faculty of Medicine, Universitas Airlangga, Surabaya, Indonesia. \\ 2 Department of Ophthalmology, Faculty of Medicine, Universitas Airlangga - Dr. Soetomo General Hospital Surabaya, \\ Indonesia. \\ ${ }^{3}$ Department of Radiology, Faculty of Medicine, Universitas Airlangga - Dr. Soetomo General Hospital Surabaya, Indonesia.
}

\section{A B S T R A C T}

Introduction: Retinoblastoma is a cancer with the highest incidence in children and the second type of cancer that most often causes death in children in Indonesia. The level of delay in attending treatment for retinoblastoma patients in Dr. Soetomo General Hospital Surabaya is still high, because generally the patients come with an advanced stage, they are already in serious condition or with a poor prognosis. Treatment delay from the patients can be caused by the patients that are not feeling disturbed by the disease, not aware of the dangers of the disease, feel afraid, have no cost, the family does not allow them to see the doctor, and the health facilities are unaccessable. One of the factors that influence decision making whether or not someone comes to seek treatment is their socioeconomic status. The aim of this research is to analyze the correlation between family socioeconomic status with the delayed treatment for retinoblastoma patients at Dr. Soetomo General Hospital Surabaya.

Methods: This research used observational analytic cross-sectional study. This research was conducted with the help of 33 retinoblastoma patients and families of retinoblastoma patients in the Outpatient Unit of the Poli Onkologi Satu Atap (POSA) Mata at Dr. Soetomo General Hospital Surabaya, and was taken by total sampling.

Results: The results were obtained from 33 samples, $18.2 \%$ of patients came with a good prognosis, and $81.8 \%$ of patients came with a poor prognosis. The Fisher's Exact Test analysis $(\alpha=0.05)$ was used to determine the correlation between the father's educational level and the delayed treatment of retinoblastoma patients $(p=$ 0.322 ), correlation between the mother's educational level and the delayed treatment of retinoblastoma patients $(p=0.129)$, correlation between the father's level of occupation and the delayed treatment of retinoblastoma patients $(p=$ 0.028), correlation between the mother's occupational level and the delayed treatment of retinoblastoma patients $(p=0.640)$, correlation between the family income level and the delayed treatment of retinoblastoma patients $(p=0.026)$.

Conclusion: There were significant correlation between father's occupational level and family income level with the delayed treatment of retinoblastoma patients. Meanwhile there were no significant correlation between father's educational level, mother's educational level, and mother's occupational level with the delayed treatment of retinoblastoma patients.

* Correspondence: hendriands@yahoo.com

JUXTA: Jurnal Ilmiah Mahasiswa Kedokteran Universitas Airlangga

p-ISSN: 1907-3623; e-ISSN: 2684-9453

DOI: 10.20473/juxta.V10I22019.52-55

Open access under Creative Commons Attribution-ShareAlike 4.0 International License (CC-BY-SA)
ARTICLE INFO

Article history:

Received 13 August 2019

Received in revised form 20

August 2019

Accepted 27 August 2019

\section{Keywords:}

Retinoblastoma,

Prognosis,

Delayed Treatment,

Family Socioeconomic Status. 


\section{Introduction}

One of the most common intraocular malignancies in children is retinoblastoma. ${ }^{1}$ The retinoblastoma can attack a child since being in the womb of the mother until the age of 5 years. $^{2}$ The frequency of retinoblastoma occurs approximately 1 in every 20,000 births. ${ }^{3}$ In Indonesia, according to the data from the Indonesian Cancer Registration System (SriKanDI) in 2005-2007, the estimated incidence of retinoblastoma in children (0-17 years) is 2.4 per $100,000 .{ }^{4}$ In East Java, in 2010-2012, there were 44 retinoblastoma patients at Dr. Soetomo General Hospital Surabaya with an average age of 44.64 months, $86.36 \%$ of cases are unilateral and $13.64 \%$ of cases are bilateral. From the 44 cases, patients with stage III-a were the most dominant patients found as many as 27 patients. ${ }^{5}$ Early diagnosis is the key of retinoblastoma. ${ }^{6}$ Early intervention is very important for the success of retinoblastoma treatment. ${ }^{7}$ In fact, cases that come in general are the cases with an advanced stage. In the case of the patients, if found with an advanced stage then the patient's prognosis becomes worse..$^{4,8}$

Based on the data from the Indonesian Ministry of Health, the mortality rate due to retinoblastoma is the second cause of death after leukaemia. It is because most of patients arrive late or are already in an advanced stage. ${ }^{4} 90 \%$ delay in diagnosing the retinoblastoma in Indonesia comes from the parents of the children. One of the factors that influence the decision making for whether or not someone needs the treatment is their socioeconomic status. $^{9}$

Families, particularly parents, are the closest people to a child's life. In the case of retinoblastoma, generally at the age of 0-5 years, the child has not been able to explain how the pain/abnormality are felt. Thus, the role of the family, especially parents, is very important to recognize the presence of signs and symptoms that arise in the child. Then, they make the decision to do or not an examination regarding the condition of their children and health services that will be chosen as a place of treatment. $^{6}$

Looking at the high rate of retinoblastoma in children and the retinoblastoma as the second type of cancer that most often causes death in children in Indonesia because generally the patients come late, the researcher are interested in conducting a research to see whether there is a relationship between family socio-economic level and the late arrival of retinoblastoma patients at Dr. Soetomo General Hospital Surabaya.

\section{Methods}

This study was an observational analytic study using a cross sectional study design. The population was all retinoblastoma patients at Poli Onkologi Satu Atap (POSA) Mata Dr. Soetomo General Hospital Surabaya in January - September 2018. The samples of this study were taken by total sampling.

There were two variables in this study, namely the independent variable and dependent variable. The independent variable covers the socio-economic level of the family including the level of education, employment, and family income.

The level of education is grouped according to the Law No. 20 of 2003 into low levels of education (not attending school, graduated from elementary school, graduated from junior high school), secondary education level (graduated from high school), and higher education level (graduated from college).

Income levels are grouped according to the 2008 Central Bureau of Statistics (BPS) into high income groups (>Rp.2,500,000.00 per month), moderate income groups (Rp.1,500,000.00 - Rp.2,500,000.00 per month), and low income groups (<Rp.1,500,000.00 per month).

The dependent variable is the delay in coming to treatment. The delay of patients attending to the treatment was seen from the patient's prognosis when diagnosed with retinoblastoma at Dr. Soetomo General Hospital Surabaya. The data were obtained from the patient's medical record document. The classification of Reese and Ellsworth (1958) was used for the assessment of the patient's prognosis namely good prognosis (stage I, II, III) and poor prognosis (stage IV, V, extraocular)

Primary data were obtained through interviews and filling out questionnaires. Secondary data were obtained from the patient's medical record. Data analysis used univariate and bivariate analysis using the Fisher Exact Test correlation test (alternative test from chi square test) at a significance level of $95 \%(\alpha=0.05)$. The statistical test results are said to be significant if the value of $\rho$ value $<0.05$ and not significant if $\rho$ value $>0.05$.

\section{Results}

This research was conducted during January September 2018 in the Outpatient Unit of the Poli Onkologi Satu Atap (POSA) Mata at Dr. Soetomo General Hospital Surabaya. The number of patients and their families who were willing to become respondents were 33 samples, 6 patients $(18.2 \%)$ came with a good prognosis while 27 patients $(81.8 \%)$ came with a poor prognosis. Table 1 showed the characteristics of retinoblastoma patients. Table 2 showed the socio-economic characteristics of the family. Table 3 , as the results of the bivariate analysis, showed that the level of father's education, the level of mother's education, and the level of mother's occupation, had a p-value of more than 0.05 , which means that it does not have a significant relationship to the delayed treatment of retinoblastoma patients at Dr. Soetomo General Hospital Surabaya. Testing on the variables of father's occupational level and family income level has a p-value of less than 0.05 , which means that it has a significant relationship towards the delayed treatment of retinoblastoma patients at Dr. Soetomo General Hospital Surabaya.

Table 1. Characteristics of retinoblastoma patients at Dr. Soetomo General Hospital Surabaya.

\begin{tabular}{llll}
\hline \multirow{2}{*}{$\begin{array}{l}\text { Age } \\
\text { (month) }\end{array}$} & Variable & $\mathbf{n}$ & $\%$ \\
\cline { 2 - 4 } & $0-<12$ & 3 & 9.1 \\
\cline { 2 - 4 } & $12-<36$ & 18 & 54.5 \\
\hline
\end{tabular}




\begin{tabular}{llll}
\cline { 2 - 4 } Sex & $36-<60$ & 7 & 27,3 \\
\multirow{4}{*}{ Laterality } & $>60$ & 3 & 9.1 \\
\cline { 2 - 4 } Stadium & Male & 17 & 51.5 \\
& Female & 16 & 48.5 \\
\cline { 2 - 4 } & Unilateral & 29 & 87.9 \\
& Bilateral & 4 & 12.1 \\
\cline { 2 - 4 } & Intraocular & 20 & 60.6 \\
& $($ II) & $(6)$ & $(18.2)$ \\
& $($ IV) & $(3)$ & $(9.1)$ \\
Clinical & (V) & $(11)$ & $(33.3)$ \\
symptoms & Extraocular & 13 & 39.4 \\
\cline { 2 - 4 } & Proptosis & 12 & 36.4 \\
& Hiperemi & 15 & 45.4 \\
& Chemosis & 5 & 15.2 \\
& Leukocoria & 30 & 90.9 \\
& Strabismus & 6 & 18.2 \\
& Amblyopia & 2 & 6.1
\end{tabular}

Table 2. Socio-economic status of the family.

\begin{tabular}{llll}
\hline & Variable & $\mathbf{N}$ & $\%$ \\
\hline \multirow{2}{*}{ Father's } & Low & 16 & 48.5 \\
education & Middle & 16 & 48.5 \\
& High & 1 & 3.0 \\
\hline \multirow{2}{*}{ Mother's } & Low & 19 & 57.6 \\
education & Middle & 11 & 33.3 \\
& High & 3 & 9.1 \\
\hline \multirow{2}{*}{ Father's } & Low & 20 & 60.6 \\
occupation & Middle & 10 & 30.3 \\
& High & 3 & 9.1 \\
\hline \multirow{2}{*}{ Mother's } & Unemployed & 23 & 69.7 \\
\multirow{2}{*}{ Family } & Working & 10 & 30.3 \\
income & Low & 20 & 60.6 \\
& Middle & 8 & 24.2 \\
& High & 5 & 15.2 \\
\hline
\end{tabular}

prognosis. This is in line with the research of Canturk, et al. in 2010 which stated that in developing countries, the diagnosis of retinoblastoma is often enforced at an advanced stage where the extraocular dissemination has occurred so that the ocular survival rate and patient survival rate are low. ${ }^{10}$ The study of Sitorus, et al. in 2015 also stated that in Indonesia, after parents visit the doctor to consult, the parents would leave the hospital to reconsult with their extended families. Then, the child was never brought back by the family or brought back a few months later after the family has tried all kinds of traditional medicine and massive proptosis has developed so that in this situation there is no hope for the patient's life. ${ }^{11}$

Based on the results of the study, it was found that retinoblastoma patients who came with poorer prognosis mostly occur at the lower level of father's education and occupation, the lower mother's education level, the group of non-working mothers, and the lower family income level. The retinoblastoma patients who came with a good prognosis are mostly found at the middle-level of father's education and occupation, the lower mother's education level, the group of non-working mothers and middleincome family level.

There was no relationship between the level of father's education and the delayed treatment of retinoblastoma patients at Dr. Soetomo General Hospital Surabaya. Likewise, at the level of mother's education, there was no relationship between the level of mother's education and the delayed treatment of retinoblastoma patients at Dr. Soetomo General Hospital Surabaya. This is in line with the opinion of Hikmanti, et al. in 2014 which stated that there is no relationship between the level of education and

Table 3. Bivariate Analysis (Fisher's Exact Test's Result).

\begin{tabular}{lllll} 
& & \multicolumn{3}{l}{ The Delayed Treatment } \\
\cline { 3 - 5 } Variable & & $\begin{array}{l}\text { Good } \\
\text { Prognosi }\end{array}$ & $\begin{array}{l}\text { Poor } \\
\text { Prognosi }\end{array}$ & P-value \\
& & s (\%) & s (\%) & \\
\hline \multirow{2}{*}{ Father's } & Low & $1(16.7)$ & $15(55.6)$ & \\
education & middle & $5(83.3)$ & $11(40.7)$ & 0.322 \\
& high & $0(0.0)$ & $1(3.7)$ & \\
\hline \multirow{2}{*}{ Mother's } & Low & $3(50.0)$ & $16(59.3)$ & \\
education & middle & $1(16.7)$ & $10(37.0)$ & 0.129 \\
& high & $2(33.3)$ & $1(3.7)$ & \\
\multirow{2}{*}{ Father's } & Low & $1(16.7)$ & $19(70.4)$ & \\
occupation & middle & $4(66.7)$ & $6(22.2)$ & 0.028 \\
& high & $1(16.7)$ & $2(7.4)$ & \\
\hline \multirow{2}{*}{ Mother's } & unemploye & $5(83.3)$ & $18(66.7)$ & \\
occupation & d & $1(16.7)$ & $9(33.3)$ & 0.640 \\
& working & & & \\
\hline \multirow{2}{*}{ Family } & Low & $1(16.7)$ & $19(70.4)$ & \multirow{2}{*}{0.026} \\
income & middle & $3(50.0)$ & $5(18.5)$ & \\
& high & $2(33.3)$ & $3(11.1)$ & \\
\hline
\end{tabular}

the delay in attending treatment for breast cancer patients. ${ }^{12}$ The results of Sari's study in 2015 also stated that there is no significant relationship between the level of education and the late arrival of treatment in fracture patients using Jamkesmas (National Health Insurance). ${ }^{13}$

There was a relationship between the level of father's occupation and the delayed treatment of retinoblastoma patients at Dr. Soetomo General Hospital Surabaya. At the level of mother's occupation, there was no correlation between the levels of mother's occupation with the delayed treatment of retinoblastoma patients at Dr. Soetomo General Hospital Surabaya. Basically, the low level of occupation in this study is the average type of occupation which income is not permanent. In a research conducted by Sarofah, occupational factors can be a family background. In this case the parents cannot carry out their roles properly; parents will often be outside the home because of their busy work. ${ }^{14}$ One characteristic of families in Indonesia is that it is generally led by a husband (father) as the dominant head of the household in making decisions even though the process is through deliberation and consensus. ${ }^{15}$ In this study, there were differences in the relationship between the level of father's occupation and the relationship between the level of mother's occupation and the delay in retinoblastoma patients coming to treatment, because generally the decision to bring the child to attend the treatment was 
determined by the husband/father as the head of the family. ${ }^{15}$

There was a relationship between the level of family income and the delayed treatment of retinoblastoma patients at Dr.Soetomo General Hospital Surabaya. In a study done by Mukharomah in 2015, also mentioned there was a relationship between the level of income and the late diagnosis of cervical cancer patients in Semarang Hospital. ${ }^{16}$ One of the factors that causes the delays in treatment is the medical costs that are felt especially at low (poor) income levels. They will assume that the symptoms of the illness are not serious as an excuse for medical expenses. ${ }^{17}$ The study done by Taffa and Chepngenoin in the slums of Nairobi in 2015 also stated that mothers with low socio-economic levels usually wait and observe their children in some time before they visit the health care center, so that when the children are taken to health services, they are already in a severe condition. ${ }^{18}$

Ignorance of the patient's family regarding retinoblastoma, medical action that will be carried out, also if there is a national health insurance that helps to pay for the treatment of cancer patients are the cause of delays in coming to treatment for retinoblastoma patients. ${ }^{11,} 17,19$ The existence of the JKN (National Health Insurance) program which began in 2014 with the aim to fulfil the basic needs of proper public health should be the answer to the cost problem as a reason for the late arrival of treatment for patients with retinoblastoma. ${ }^{20}$

However, in addition to medical expenses feared by the family, the cost of transportation and the accommodation during the treatment are a matter of consideration for the family when they want to refer the patients. The distance between referral hospitals prevents the families from taking the patients as soon as possible and conducts repeated consultations, especially for the families with economic constraints (middle to lower economy). ${ }^{17,19,21}$

This has not been the focus of the government, even though the government has provided health insurance but it has not been a solution to the delay in medical treatment, especially for the middle and lower classes. This, of course, must be a consideration of the government to realize the appropriate health services for Indonesian. Besides, improving the regional health facilities must be taken, so that there is closer referral hospital for treatment in each region, particularly the cases of retinoblastoma as well as providing and promoting the shelters for health insurance participants. These things will greatly help the referral patients who are far from the referral hospital, especially for outpatients who carry out the health checks while waiting for the surgery/treatment schedule.

The limitations that could exist in this study were that samples were lacking because of incomplete medical records and respondents who did not agree to be interviewed were the obstacles for researchers to obtain more accurate data and a significant relationship regarding the delay in coming to treatment for retinoblastoma patients.

\section{Conclusion}

There was significant correlation between father's occupational level and family income level with the delayed treatment of retinoblastoma patients. Meanwhile there was no significant correlation between father's educational level, mother's educational level, and mother's occupational level with the delayed treatment of retinoblastoma patients.

\section{Acknowledgement}

1. The health workers in the Outpatient Unit of the Poli Onkologi Satu Atap (POSA) Mata at Dr. Soetomo General Hospital Surabaya.

2. Division of Research and Development Dr. Soetomo General Hospital Surabaya.

\section{CONFLICT OF INTEREST}

The author stated there is no conflict of interest in this study.

\section{REFERENCES}

1.Garza R and Gombos DS. Incidence, Prevalence and Epidemiology. Retinoblastoma: Clinical Advances and Emerging Treatment Strategies. P. 18-23.

2.Yun J, Li Y, Xu C-T and Pan B-R. Epidemiology and Rb1 Gene of Retinoblastoma. Int J Ophthalmol. 2011; 4: 103-9.

3.Donaldson S, Egbert P and Lee W. Retinoblastoma. In: Pizzo PA and Poplack DG, (Eds.). Principles and Practice of Pediatric Oncology. Philadelphia: Lippincott Williams \& Wilkins, 1993, P. 683-96.

4.Indonesia KKR. Pedoman Penemuan Dini Kanker pada Anak: (2011).

5.Soebagjo HD, Prastyani R, Sujuti H, Lyrawati D and Sumitro SB. Profile of Retinoblastoma in East Java, Indonesia. World Journal of Medicine and Medical Science Research. 2013; 1: 51-6.

6.Organization WH. Retinoblastoma: 2014 Review of Cancer Medicines on the WHO List of Essential Medicines: 1-10 (2014).

7.Canty CA. Retinoblastoma: An Overview for Advanced Practice Nurses. Journal of the American Academy Of Nurse Practitioners. 2009; 21: 149-55.

8.Chantada GL, Qaddoumi I, Canturk S, et al. Strategies to Manage Retinoblastoma in Developing Countries. Pediatric Blood \& Cancer. 2011; 56: 341-8.

9.Indonesia DKR. Pharmaceutical Care untuk Penyakit Tuberkulosis. Jakarta: Direktorat Bina Farmasi Komunitas dan Klinik, Direktorat Jenderal, Bina Kefarmasian dan Alat Kesehatan, Departemen Kesehatan Republik Indonesia, 2005.

10.Canturk S, Qaddoumi I, Khetan V, et al. Survival of Retinoblastoma in Less-Developed Countries Impact of Socioeconomic and Health-Related Indicators. The British Journal of Ophthalmology. 2010; 94: 1432-6.

11.Sitorus RS, Moll AC, Suhardjono S, et al. The Effect of Therapy Refusal Against Medical Advice in Retinoblastoma Patients in a Setting Where Treatment Delays are Common. Ophthalmic Genetics. 2009; 30: 31-6. 
12. Hikmanti A and Adriani Fhn. Analisis Faktor-faktor yang Mempengaruhi Keterlambatan Pengobatan pada Wanita Penderita Kanker Payudara. Semarang: Universitas Muhammadiyah Semarang, 2014.

13.Sari A. Faktor-faktor yang Berhubungan dengan Keterlambatan Berobat pada Pasien Patah Tulang yang Menggunakan Sistem Pembiayaan Jamkesmas. Semarang: Universitas Diponegoro, 2012.

14.Sarofah N. Perbedaan Peran Ayah dan Ibu dalam Pemberian Pendidikan Kesehatan Reproduksi Remaja di Keurahan Ngampilan Yogyakarta. Yogyakarta: Universitas 'Aisyiyah Yogyakarta, 2017.

15.Ali Z. Pengantar Keperawatan Keluarga. Jakarta Utara: Penerbit Buku Kedokteran EGC, 2006.

16.Mukharomah Ki. Faktor-faktor yang Berhubungan dengan Keterlambatan Diagnosis Penderita Kanker Leher Rahim di RSUD Kota Semarang Tahun 2014. Semarang: Universitas Negeri Semarang, 2015.

17.Taber JM, Leyva B and Persoskie A. Why Do People Avoid Medical Care? A Qualitative Study Using National Data. Journal of General Internal Medicine. 2015; 30: 290-7.

18. Taffa N and Chepngeno G. Determinants of Health Care Seeking for Childhood Illnesses in Nairobi Slums. Tropical Medicine \& International Health : TM \& IH. 2005; 10: 240-5.

19.Sukardja IDG. Onkologi Klinik. Surabaya: Airlangga University Press, 2000.

20.Indonesia KKR. Bahan Paparan Jaminan Kesehatan Nasional (JKN). Jakarta: Bahan Paparan Jaminan Kesehatan Nasional (JKN), 2014.

21. Hawari D. Kanker Payudara Dimensi Psikoreligi. Jakarta: Badan Penerbit Fakultas Kedokteran Universitas Indonesia, 2004. 